\title{
3次元機能光メタマテリアルとその加工法
}

\author{
田中拓男 \\ 国立研究開発法人理化学研究所 田中メタマテリアル研究室, フォトン操作機能研究チーム ( テ351-0198 埼玉県和光市広沢2-1) \\ 東京工業大学 (テ226-8503 神奈川県横浜市緑区長津田町4259)
}

\section{Three-dimensional Metamaterials and Their Fabrication Techniques}

\author{
Takuo TANAKA
}

RIKEN, Metamaterials Laboratory and Innovative Photon Manipulation Team, Hirosawa 2-1, Wako, Saitama 351-0198 Tokyo Institute of Technology, 4259 Nagatsuta-cho, Midori-ku, Yokohama, Kanagawa 226-8503

(Received September 16, 2015)

\begin{abstract}
Stereoscopic structure is essential to realize three-dimensional functional metamaterials. Several fabrication techniques for such a stereoscopic metamaterial structure are reviewed, and as a novel and promising technique for the large area 3D metamaterials, metal-stress driven self-folding method, which uses electron beam lithography and self-organized formation of resonator rings using residual stress of metal thin films, is introduced. As an example of 3D functions of metamterial, isotropic effective index of 0.35 was experimentally demonstrated at $30 \mathrm{THz}$.
\end{abstract}

Key Words: Metamaterials, Resonator, Three-dimensional, Self-organization

1. はじめに

2000年にSmithが発表したマイクロ波帯で動作するメ タマテリアルは, 直径約 $6 \mathrm{~mm}$ 共振器で構成されてお り立体的な構造を持っていた ${ }^{1,2)}$. その後, この分野の トレンドの1つとして, 動作帯域の高周波数化が積極的 に試みられ, それに伴ってメタマテリアルの構造は微細 化していった．2004年には1 THzで動作するメタマテリ アルが報告されたが, このメタマテリアルでは, 線幅 $4 \mu \mathrm{m}$, 一辺 $26 \mu \mathrm{m}$ の素子を作るために特殊な光リソグラ フィー法が使われ，その構造は基板表面に作製された平 面状のものになった ${ }^{3)}$. その後, さらなる高周波数化と ともにより小さな構造が必要となり, 最先端の光リソグ ラフィーや電子線リソグラフィー法が導入されてメタマ テリアルの構造は平面状のものがほとんどとなった。も ちろん立体的なメタマテリアルの加工法も試みられた が4,5), 素子が小さくなればなるほど立体的な構造を作 るのは難しくなり, 平面状もしくはそれらを積層したメ タマテリアルが目立つようになった。

しかし, 高い周波数帯域においても立体的なメ夕マテ リアルの需要は大きく, 平面状のメタマテリアルが多い のは, 単に現在の微細加工技術が立体的な構造の作製を 苦手としているからである，本稿では，立体的なメ夕マ テリアルを加工するために開発・提案された加工技術を 概観しながら, 我々の取り組みを紹介したい.

\section{3次元構造メタマテリアルと3次元機能メタマテリアル}

動作周波数が光学領域にあるメタマテリアルは光メ夕 マテリアルと呼ばれる。 この光メタマテリアルでは, 特 定の周波数の光波と共鳴するような構造を利用すること で光との相互作用を高め, 屈折率などの光学特性の制御 範囲を向上させている，この共鳴構造の基本素子となる 1つ1つの共振器は, 物質を構成する原子や分子と同じア ナロジーから, メ夕原子やメ夕分子などと呼ばれてい る.

光メタマテリアルのメタ原子の大きさは, 波長との関 係からおよそ数十nmになる。このサイズはデカナノ (decanano) サイズとも呼ばれ, 最先端の微細加工技術を 使えば何とか加工できるが，原子や分子よりは2～3桁大 きく，ちょうど人類がもつ加工技術が最も苦手とする領 域に位置している.

このメタ原子の代表例がFig. 1 (a)に示す分割リング共 振器 (Split-Ring Resonator: SRR) である ${ }^{6)}$ 。このSRRはも ともとマイクロ波周波数で動作するように設計されたも ので, 可視光のような高周波数の光波では，このSRRを 単一リング化したSSRR (Single SRR) 構造 (Fig. 1(b))が適 切である ${ }^{7,8)}$ 。このSSRRは, リング状の導体がインダク タンス成分を，またリングに導入した切れ込みがキャパ シタンス成分を担い，これら2つでLC共振回路を形成し ている。ささらにリング部は磁場と相互作用するアンテナ の機能も兼ねている。このアンテナ部は, それを垂直に 


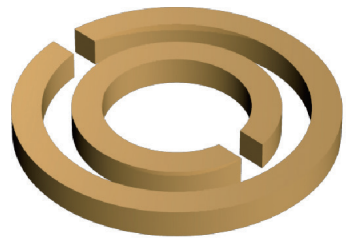

(a)

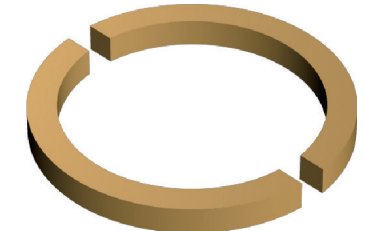

(b)
Fig. 1 Split-ring resonators (SRR). (a) Double ring SRR that is designed at microwave frequency region. The gap between two rings works as capacitor. (b) Single ring SRR is advantageous for visible range operation owing to small capacitance.

貫く磁場成分とのみ相互作用するので, SSRRがメタマ テリアルの素子として動作するのは, 光の磁場がSSRR を含む面に対して垂直に振動している場合だけになる。

SSRRに限らず，共振型のメ夕原子は必ず光波と相互作 用するアンテナ部を持つが，等方的な放射特性を持つア ンテナは存在しないので, メ夕原子の光学特性も必然的 に異方的になる。

ここで, メタマテリアルの構造と機能のそれぞれにつ いてその次元を考察する.

Fig. $2(\mathrm{a})$ のように, SRRが $x-y$ 平面内に扔かれている 状況を考えると, このSRRは平面状なので構造としては 2次元である. 一方, 磁気共振器としての機能は $z$ 方向の 磁場にしか機能しないので, 機能の次元は1次元であ る. すなわち構造と機能とでは次元が異なっている. 次 に, このSRRがz方向に積層された構造を考える。この 場合, 構造は3次元になるが, やはり z軸方向の磁場のみ (a)

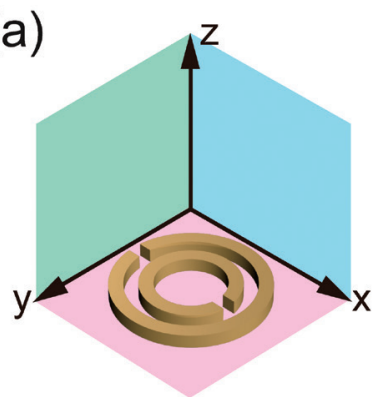

(c)

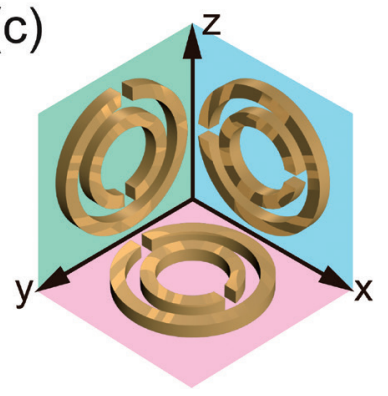

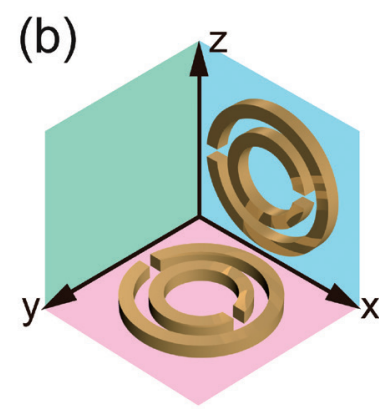

(d)

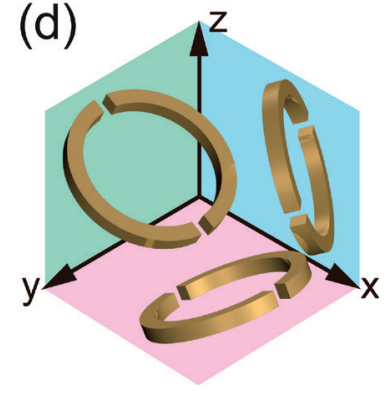

Fig. 2 Relationship between the dimension of metamaterial structure and its functions. (a) $2 \mathrm{D}$ structure but 1D function, (b) Stereoscopic structure with 2D functions, (c) 3D in both structure and functions, (d) Randomly orientation of meta atoms for isotropic property.
に応答するので機能は1次元である，次に, $x-z$ 面に SRRを1つ付け加えると, 構造としては立体的で3次元に なるが, 機能はやはり次元が1つ落ちて2次元である (Fig. $2(\mathrm{~b})) . x-y=z$ 空間のどの方向に振動する磁場にも 応答する3次元的な機能を得るには, $x=z$ 面にもSRRを 付加してメ夕原子を立方体の全ての面に配置させるか (Fig. 2(c))，もしくはメ夕原子をランダムに分散させな ければならない(Fig. 2(d)).

このように, 共振器を利用したメタマテリアルではそ の構造の次元と機能の次元は必ずしも一致しない，そし て, 3次元的な機能を獲得するには，必ず立体的な3次元 構造が必要になる。そこで, 本稿では, メタマテリアル の構造に着目してその次元を議論するときは,「立体」 「平面」といった言葉を用いて「立体メタマテリアル」のよ うに表現し，機能の次元を議論するときは1次元，2次 元，3次元を用いることにする.

3次元メタマテリアルの例の1つは, 等方的な光学特性 を示すメタマテリアルである。すなわち立体メタマテリ アル構造は, 等方性メタマテリアル得るための必要条件 である。

\section{3. 立体メタマテリアルのトップダウン的加工法}

これまで我々は，等方的な特性を持つ光メタマテリア ルの実現を目標の1つとし，そのために必要となる立体 的なメタマテリアルの加工技術の開発を続けてきた.

我々が最初に取り組んだのは，レーザーを用いて立体 的な金属微細構造を加工する手法の開発であった旦11.

これは二光子還元法と呼ばれ，フェムト秒レーザーを用 いて金属イオンを局所的に還元することで, 微細な三次 元金属構造を直接空間中に作り出す技術である。我々は この技術を用いて中赤外光 $(18 \mathrm{THz})$ の磁場成分と直接 相互作用するメタマテリアルを試作した ${ }^{12}$.

これ以外にも，二光子重合法で作製した3次元樹脂構 造の表面を選択的に金属化することで，メ夕原子を作製 する手法を開発した ${ }^{13,14)}$ ：二光子重合法では，マイクロ レンズアレイでレーザー光を複数のスポットに分割し, それらを用いて大量のメ夕原子を同時に加工する技術も 検討し，大規模なメタマテリアル構造の作製技術の開発 に取り組んだ(5)。またドイッのWegenerらは，二光子重 合法で作製した立体的な樹脂構造の表面をCVD法で金 属化する手法や ${ }^{16)}$ ，樹脂構造をメタマテリアルの鋳型と して利用し，樹脂内部に立体的に作製した空隙の中に めっき法を用いて金を析出させることで，立体的なメ夕 マテリアルを作製する手法を提案している17).

二光子還元法も二光子重合法もレーザービームを高精 度に制御しながら構造を形成する手法であり，このよう な手法はトップダウン的加工法と呼ばれる. 光リソグラ フィー法や電子リソグラフィー法もトップダウン的加工 法であり, トップダウン的手法は, 半導体集積回路の加 工をはじめとする微細加工技術の主流の1つである.

このトップダウン的加工法に共通する最大の特徵は, 加工プロセスを精密に制御することで，比較的自由な形 
状の構造物を高い精度で加工できる事である。しかしそ の反面, 後で述べるボトムアップ型の加工法と比較する と消費するエネルギーが大きい事や，一般に加工速度が 遅くて時間がかかるという欠点がある。そのため，トッ プダウン的手法で作製したメタマテリアルは，どうして もそのサイズが小さいものに限られてしまい, 試作した メタマテリアルの特性評価にも苦労するという課題が あった。

\section{4. メタマテリアルのボトムアップ的加工法}

我々は, トップダウン的加工法が持つ問題を解決する ために，物質が自己組織的に設計した構造を形成するよ うなボトムアップ的手法の導入を試みた。例えば，単一 リングのSRRがナノメートルサイズの微小金属粒子を円 環状に配列させたものと等価であることに着目し，化学 的に合成した金属ナノ粒子をDNA分子で円環状に連結 する手法を提案した ${ }^{18,19)}$. この手法では, 金ナノ微粒子 と人工的に設計・合成した 3 種類のDNA分子を混合し て, DNA分子のハイブリダイゼーションによって金ナ ノ微粒子が三角形に接続された構造を大量に合成するこ とに成功した(Fig. 3). これ以外にも磁性を持つ微粒子 を使って，外部から印加した静磁場を用いてメ夕原子の 構造を自己組織的に作る手法などを開発した ${ }^{20)}$ 。我々以 外にも, 東工大の彌田らは, 生物が持つさまざまな形に 着目し，これを鋳型として利用するバイオテンプレート 技術に関する研究を行い，その一例として，スピルリナ という螺旋構造を持つ藻の表面を金属コートすること で，THz波に対してキラリティを有するメタ原子を大量 に作り出す手法を報告している ${ }^{21)}$.

このようなボトムアップ的加工法を用いる利点は, 消 費エネルギーが少なく, 短時間に大量の構造物が得られ る事である。しかしプロセス中に形状が不完全なものや 不要な副生成物が発生したり, 加工できる形状が比較的 単純なものに制限されているという欠点がある。

\section{Metal-stress driven self-folding method}

このように, トップダウン的加工法もボトムアップ加

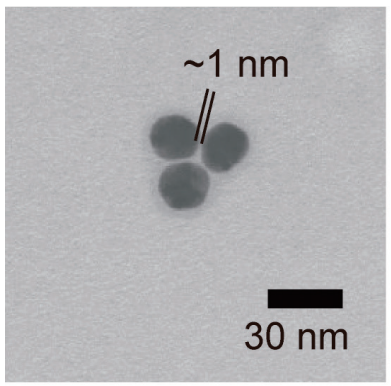

(a)

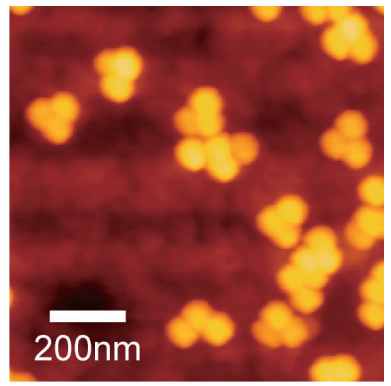

(b)
Fig. 3 Triangle assembly of Au nanoparticles using DNA templating technique. $1 \mathrm{~nm}$ gaps between $\mathrm{Au}$ nanoparticles work as capacitance of SRR.
工法もそれぞれ長所と短所を持っている，興味深いの は，両者の特性が相補的な事である。そこで，これら2 つの手法を融合させて利用することで, 双方の長所を組 み合わせた加工法を検討した。

我々が開発したのは，トップダウン的手法として電子 線リソグラフィー法を，そしてボトムアップ的手法とし て金属薄膜の残留応力を使った自己組織化構造形成を融 合させた手法で, Metal-stress driven self-folding法と名付 けた22,23)。 その加工プロセスの概要をFig. 4に示す.

メタマテリアルはシリコン基板の上に加工する。シリ コン基板の表面に電子線レジストとなるポリメタクリ レート(PMMA)をスピンコートし, 電子線を照射して パターニングを行う (Fig. 4(a)). 電子線リソグラフィー 法では, 複雑な形状を高精度にパターニングしようとす ると時間がかかるが, 電子線を一方向のみに走査して直 線状のパターンを描くことに限定すれば, 数 $\mathrm{mm}$ 角の領 域にでも比較的高速にパターンを描画することができ る。我々はこの特性に着目して, 線幅 $200 \mathrm{~nm}$, 長さ 2.5 $\mu \mathrm{m}$ の直線状のリボンパターンを $4 \mathrm{~mm}$ 角の領域に大量に 描画した(Fig. 4(b))。描画が終わったレジストを現像す ると電子線を描画した部分のレジスト膜が除去され，ラ インパターンの溝ができる。これに真空蒸着法を用いて ニッケルと金を蒸着した。ニッケルの膜厚は $10 \mathrm{~nm}$, 金 の膜厚は60 nmであった (Fig. 4(c)). その後, リフトオ フ法にてレジスト膜を除去すると, シリコン基板上に金 属リボン構造が形成された (Fig. 4(d))。次にシリコンを 選択的にエッチングするCF4ガスを用いた反応性イオン エッチングで等方的にエッチングした(Fig. 4(e)). エッ

(a)
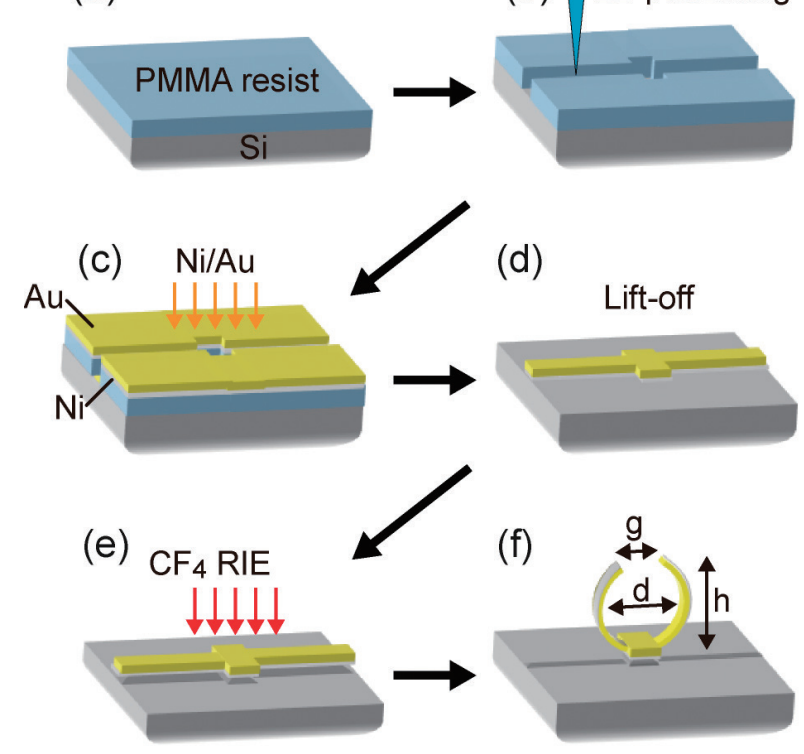

Fig. 4 Schematics of the metal-stress driven self-folding method. (a) Spin-coating of PMMA resist on $\mathrm{Si}$ substrate, (b) Electron beam lithography and development, (c) Ni and $\mathrm{Au}$ thin films deposition, (d) Lift-off for metal ribbon formation, (e) Isotropic reactive ion etching using $\mathrm{CF} 4$ gas, (f) self-organized formation of metal ring that is self-standing on Si substrate. 
チングが進むにつれて, 表面が暴露された領域に加えて 金属リボンの下側のシリコン基板もエッチングされて最 終的に金属リボンが基板から剥離される，最初のパター ニング時に，金属リボンの中央部のみ露光量を上げてお くと，それに応じて金属リボンの中央部のみが太くなっ てシリコン基板から剥離されるまでに要するエッチング 時間が長くなる。，そこで中央部が基板から剥離される直 前でエッチングを停止させると, 中央部のみがシリコン 基板に固定され，両側のリボンが剥離された状態にな る.するとニッケルと金との残留応力の違いによって, 金属リボンが湾曲してシリコン基板に対して垂直方向に 自立する金属リング構造が自己組織的に形成される (Fig. 4(f))．このようにして作製した三次元金属アレイ の走査電子顕微鏡写真がFig. 5 である. 基板に自立する 金属リングが高密度に集積化させた構造が確認できる。

この手法の特徵は, メ夕原子の機能を受け持つリング構 造が, 2 種類の金属の性質の違いを利用するだけで自己 組織的に形成される事である。

\section{3 次元メタマテリアルの基礎特性}

まず，メ夕原子が一列に配列されたメタマテリアル構 造を試作し, 分光スペクトルの入射光の偏光依存性を測 定してその異方性を確認した。 その結果がFig. 6であ る. $\mathrm{x}$ 方向に偏波した直線偏光を基板に対して垂直に入 射させ，その透過スペクトルを測定した， z軸の周りの 回転角を $\theta$ とし, 光の電場がメタマテリアルと平行に振 動している時を $\theta=0^{\circ}$ とした. 試作したメ夕原子は, 光 の電場と磁場の両方と相互作用するが， $\theta=0^{\circ}$ ではそれ ら両者との共鳴相互作用の結果, 周波数 $27.5 \mathrm{THz}$ 付近に ピークを持つ透過率の低下が観測された。この透過率の 低下は回転角 $\theta$ が増えると小さくなり， $\theta=90^{\circ}$ ではゼロ となった。

Fig. 7は, 有限要素法を用いた数值計算結果である. $\theta$ $=90^{\circ}$ では, 目立った透過率の低下は見られないが, $\theta=$ 0゚では30.2 THzをピークとする透過率の低下が見られ, 実駼結果と良く合致していることを確認した．Fig.7に は, この周波数に扔ける $\mathrm{z}$ 軸方向の電流分布も併せて示 した。この電流分布から，この透過率の低下は連流がリ ング部を円環状に流れるモードに由来することを確認し

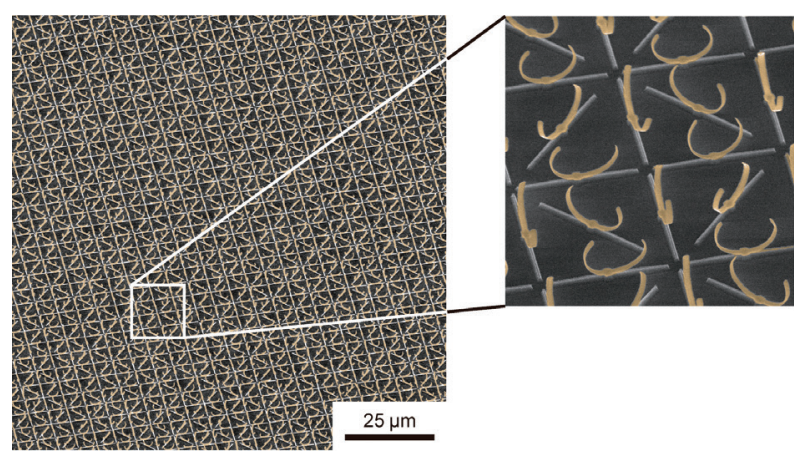

Fig. 5 Scanning electron micrograph of the fabricated 3D metamaterial.

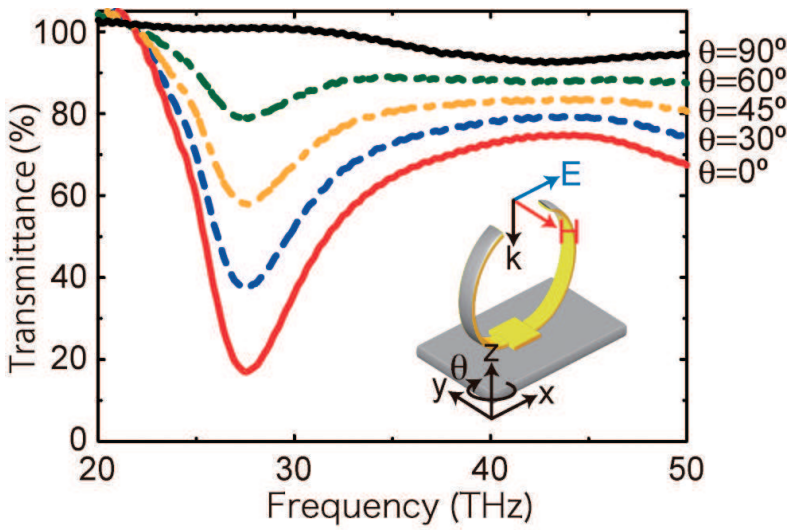

Fig. 6 Polarization dependences of the transmission spectrum of the fabricated stereo metamaterial.

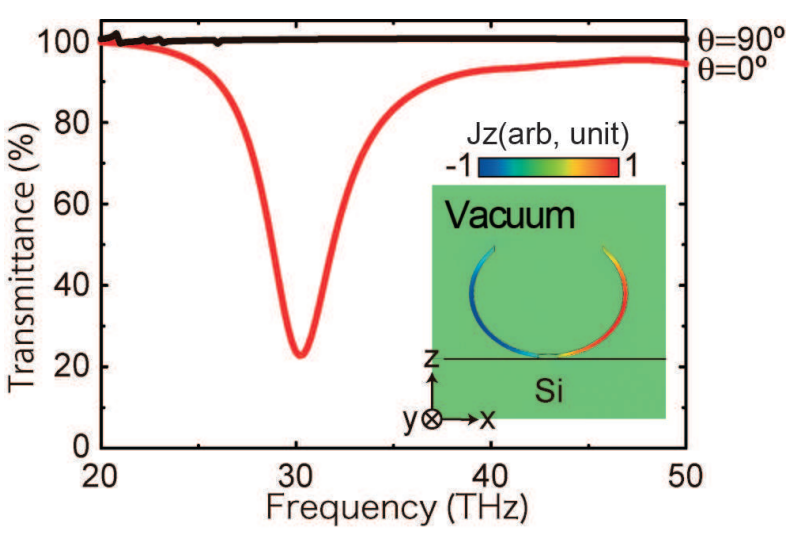

Fig. 7 Numerical calculation results using finite element method.

た。

実験結果ならびに数值計算結果を用いて, 試作したメ タマテリアルの実効的な屈折率を求めたのがFig. 8であ る。この結果から, 試作したメタマテリアルの実効屈折 率は30 THz付近で大きく変化し, $28.8 \mathrm{THz} て ゙ 1.86$, そし て32.8 THzで0.35になることがわかった。このように, 我々が試作したメタマテリアルでは特定の周波数におい て真空の屈折率も低い值が実現できた。

\section{7. 疑似等方性メタマテリアル}

Fig. 6にも示したように，メ夕原子は強い異方性を持

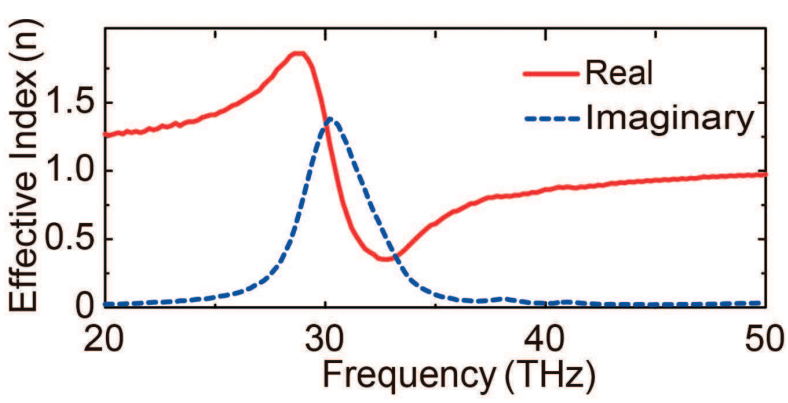

Fig. 8 Dispersion of the effective index of the fabricated 3D metamaterial. Effective index of 0.35 was appeared at $32.8 \mathrm{THz}$. 
つので，それらを一方向に並べたメタマテリアルもやは り強い異方性を持つ。そのため等方的な特性を得るに は，これらのメ夕原子を様々な方向に配向させて集積化 する必要がある。我々が開発した加工法は，プロセスの 前半でトップダウン的な電子線リソグラフィ法を利用し ているので，メ夕原子のサイズや配置間隔，配向方向を 精密に制御できる。 そこで, Fig. 9(a)に示すように, メ 夕原子が水平，垂直ならびに45度方向に配列したメ夕マ テリアルを試作してその特性を測定した。測定では，x -y平面にメタマテリアルの基板をセットし， $\mathrm{z}$ 軸周りの 回転角を $\theta$, 光の入射方向と $\mathrm{z}$ 軸とが成す角を $\phi$ とした。

Fig. 9(b)は，入射角 $\phi$ をゼロにセット(垂直入射)し， $\theta$ を 0度から90度まで変化させながら透過スペクトルの変化 をプロットしたものである、横軸が周波数, 縦軸が回転 角 $\theta$ で, 透過率を濃淡で示した。この結果から, 基本 モードに対応する吸収ピークは回転角 $\theta$ に依らず一定の 周波数と強度を示し, このメタマテリアルは垂直入射光 に対しては完全な等方性を示す事がわかった。

試作したメタマテリアルでは, メタ原子はx-z面, y - $\mathrm{z}$ 面とそれらと45度をなす面内に配置されているが， $\mathrm{x}$ 一y面に平行な方向のメ夕原子は無いので, 完全な三次 元構造ではない. しかし入射角 $\phi$ を変化させてその応答 特性を調べたところ，入射角 40 度までの入射光に対して はほぼ等方的な特性が実現されていることがわかった。

(a)
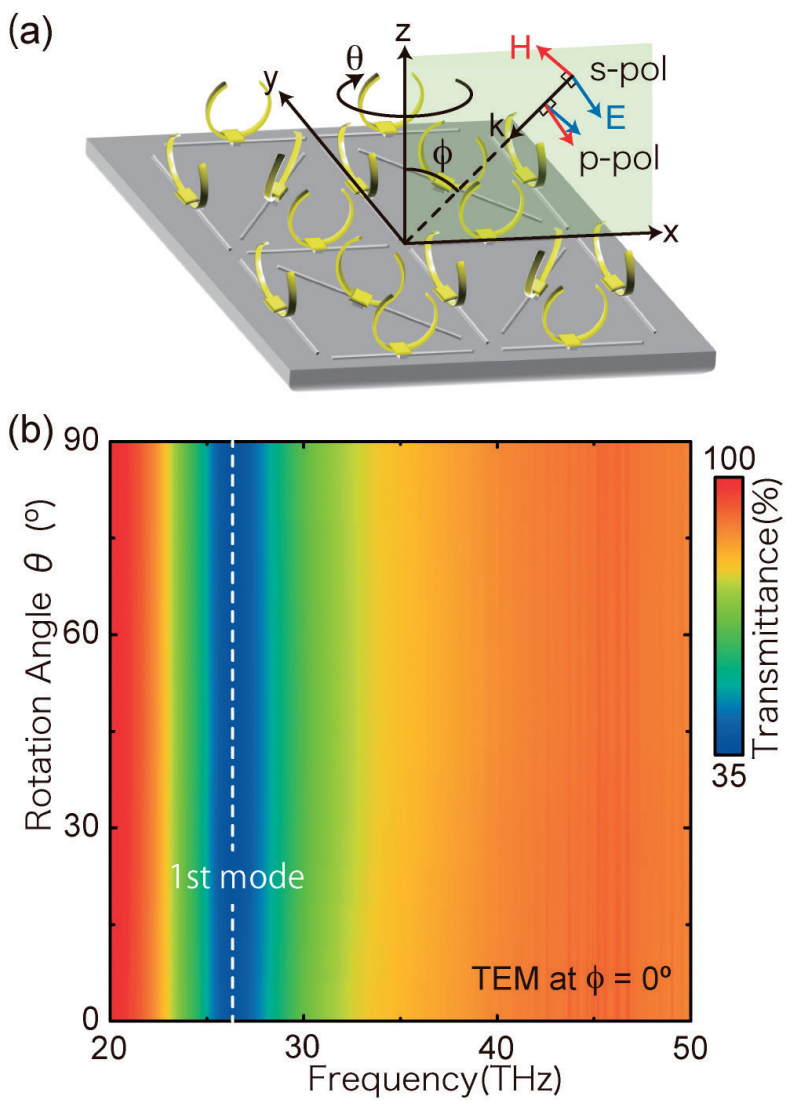

Fig. 9 Isotropic properties of 3D metamaterial. Resonant frequency was independent of the rotation angle $\theta$. (a) Schematic of measurement setup. (b) Measured transmittance of an isotropic metamaterial as a function of frequency and sample rotation angle $\theta$.
Fig. 10がその実験結果である.Fig. 10(a)，（b)はそれぞ れp偏光とs偏光に対する応答である. $27 \mathrm{THz}$ 付近の吸収 バンドは，入射角が 40 度までに限定すればほとんど変化 していないことから，この範囲では斜入射光に対しても 等方性を保持していることがわかる.

このように，本来強い異方性を持つメ夕原子を用いな がらも，それを立体的な構造に加工して様々な方位に配 向させて集積化させると，メタマテリアル全体としては 等方的な特性を示す事が実験的に実証することができ た。

\section{8. おわりに}

基本素子として極微細な共振器を用いる共振型メ夕マ テリアルでは，その構造が立体的であることと，光学的

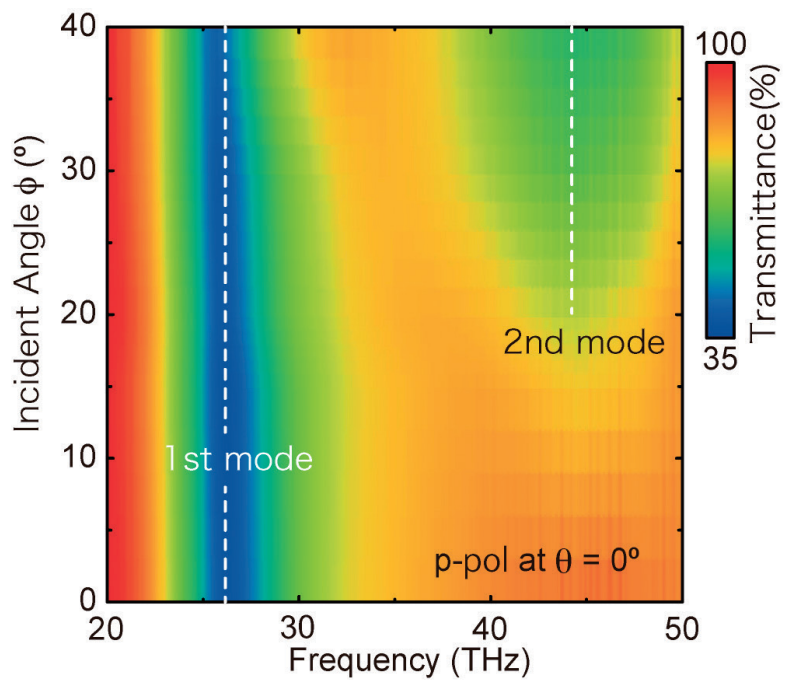

(a)

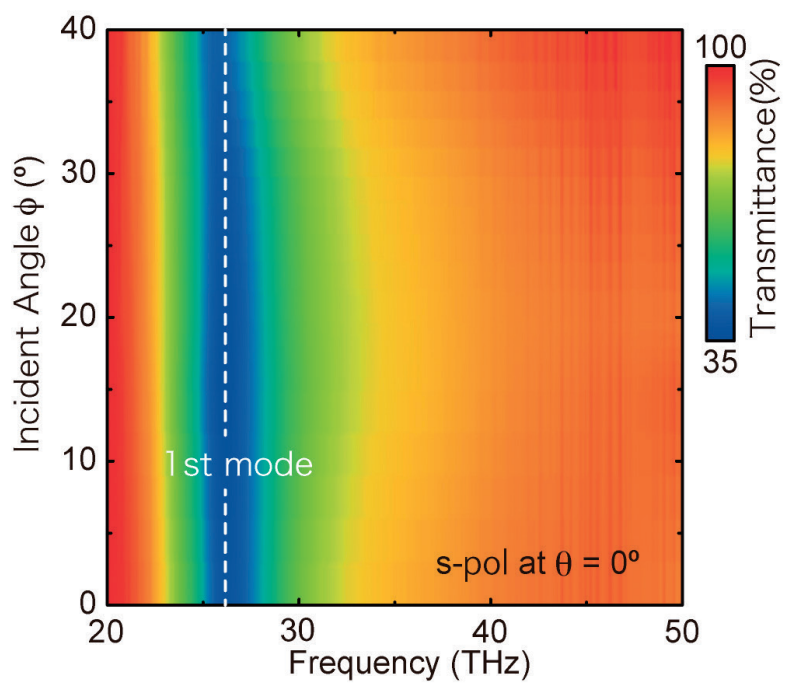

(b)

Fig. 10 Dependences of resonant properties of the 3D metamaterial on the incident angle. Isotropic optical properties are obtained up to 40 degree in incident angle. (a) Measured transmittance for p-polarization at $\theta=0$, and (b) that for s-polarization at $\theta \equiv 0$. 
な機能が3次元的にあらゆる方向に発現することとは別 であることを指摘し，3次元的な機能を有するメタマテ リアルを作り出すには，立体的な構造を持つメタマテリ アルが必要であること述べた。そして，立体的なメタマ テリアルを作り出すための加工技術をいくつか紹介する とともに，トップダウン的な加工法とボトムアップ的な 加工法とを融合させた我々の試みを紹介した。

\section{参考文献}

1) D. R. Smith, W. J. Padilla, D. C. Vier, S. C. Nemat-Nasser, and S. Shultz: Phys. Rev. Lett. 84 (2000) 4184.

2) R. Fitzgerald: Phys. Today 53 (2000) 17

3) T. J. Yen, W. J. Padilla, N. Fang, D. C. Vier, D. R. Smith, J. B. Pendry, D. N. Basov, and X. Zhang: Science 303 (2004) 1494

4) M. Rill, C. Plet, M. Thiel, I. Staude, G. Freymann, S. Linden, and M. Wegener: Nature. Commun. 7 (2008) 543.

5) J. K. Gansel, M. Thiel, M. S. Rill, M. Decker, K. Bade, V. Saile, G. Freymann, S. Linden, and M. Wegener: Science 325 (2009) 1513.

6) J. Pendry, A. Holden, D. Robbins, and W. Stewart: IEEE Trans. Microwave Theory Tech. 47 (1999) 2075.

7) A. Ishikawa, T. Tanaka, and S. Kawata: Phys. Rev. Lett. 95 (2005) 237401

8) A. Ishikawa, T. Tanaka, and S. Kawata: J. Opt. Soc. Am. B 24 (2007) 510.

9) T. Tanaka, A. Ishikawa, and S. Kawata: Appl. Phys. Lett. 88 (2006) 81107.
10) A. Ishikawa, T. Tanaka, and S. Kawata: Appl. Phys. Lett. 89 (2006) 113102.

11) Y. Cao, N. Takeyasu, T. Tanaka, X. Duan, and S. Kawata: Small 5 (2009) 1144.

12) A. Ishikawa, T. Tanaka, and S. Kawata: Appl. Phys. Lett. 91 (2007) 113118.

13) F. Formanek, N. Takeyasu, T. Tanaka, K. Chiyoda, A. Ishikawa, and S. Kawata, Appl. Phys. Lett. 88 (2006) 083110.

14) N. Takeyasu, T. Tanaka, and S. Kawata: Appl. Phys. A: Mater. Sci. Proc. 90 (2008) 205.

15) J. Kato, N. Takeyasu, Y. Adachi, H. Sun, S. Kawata: Appl. Phys. Lett. 86 (2005) 044102.

16) M. Rill, C. Plet, M. Thiel, I. Staude, G. Freymann, S. Linden, and M. Wegener: Nature Mater. 7 (2008) 543.

17) J. K. Gansel, M. Thiel, M. S. Rill, M. Decker, K. Bade, V. Saile, G. Freymann, S. Linden, and M. Wegener: Science 325 (2009) 1513.

18) T. Ohshiro, T. Zako, R. W-Tamaki, T. Tanaka and M. Maeda: Chem. Commun. 46 (2010) 6132.

19) R. W-Tamaki, A. Ishikawa, T. Tanaka, T. Zako, and M. Maeda: J. Phys. Chem. C 116 (2012) 15028.

20) K. Aoki, K. Furusawa, and T. Tanaka: Appl. Phys. Lett. 100 (2012) 181106.

21) K. Kamata, P. Zhenzi, S. Suzuki, T. Fujimori, W. Tajiri, K. Nagai, T. Iyoda, A. Yamada, T. Hayakawa, M. Ishiwara, S. Horaguchi, A. Belay, T. Tanaka, K. Takano, and M. Hangyo: Sci. Rep. 4 (2014) 4919.

22) C. Chen, C. Hsiao, S. Sun, K. Yang, P. Wu, W. Chen, Y. Tang, Y. Chau, E. Plum, G. Guo, N. Zheludev, and D. Tsai: Opt. Express 20 (2012) 9415

23) C. Chen, A. Ishikawa, Y. Tang, M. Shiao, and D. Tsai, and T. Tanaka: Adv. Opt. Mater. 3 (2015) 44. 